\title{
A Gray Whale in Magdalenian Perigord. Species identification of a bone projectile point from La Madeleine (Dordogne, France) using collagen fingerprinting
}

Une baleine grise dans le Périgord magdalénien : identification taxinomique d'une pointe de projectile en os de La Madeleine (Dordogne, France) par empreinte peptidique de masse du collagène

Jean-Marc Pétillon, François-Xavier Chauvière, Camilla Speller, Krista McGrath, Ana S.L. Rodrigues, Anne Charpentier and François Baleux

\section{(2) OpenEdition}

\section{Journals}

Electronic version

URL: http://journals.openedition.org/paleo/4736

DOI: $10.4000 /$ paleo.4736

ISSN: 2101-0420

Publisher

SAMRA

\section{Printed version}

Date of publication: 30 December 2019

Number of pages: $230-242$

ISSN: 1145-3370

Electronic reference

Jean-Marc Pétillon, François-Xavier Chauvière, Camilla Speller, Krista McGrath, Ana S.L. Rodrigues, Anne Charpentier and François Baleux, « A Gray Whale in Magdalenian Perigord. Species identification of a bone projectile point from La Madeleine (Dordogne, France) using collagen fingerprinting », PALEO [Online], 30-1 | 2019, Online since 29 May 2020, connection on 07 July 2020. URL : http:// journals.openedition.org/paleo/4736 ; DOI : https://doi.org/10.4000/paleo.4736 
A GRAY WHALE

IN MAGDALENIAN

PERIGORD.

SPECIES IDENTIFICATION

OF A BONE PROJECTILE

POINT FROM LA MADELEINE

(DORDOGNE, FRANCE)

USING COLLAGEN

FINGERPRINTING

Jean-Marc Pétillona, François-Xavier Chauvièreb, Camilla Spellerc, Krista McGrath", Ana S.L. Rodriguese, Anne Charpentiere, François Baleuxa

a. CNRS, Laboratoire Traces, UMR 5608, Maison de la recherche, Université Toulouse Jean-Jaurès, 5 allées Antonio-Machado, FR-31058 Toulouse cedex 9 - petillon@univ-tlse2.fr; francois.baleux@univ-tlse2.fr b. République et canton de Neuchâtel, Office du patrimoine et de l'archéologie, section Archéologie, Laténium, Espace Paul Vouga, CH-2068 Hauterive - francois-xavier.chauviere@ne.ch

c. Department of Anthropology, University of British Columbia, CA-Vancouver, BC - camilla.speller@ubc.ca

d. BioArCh, Department of Archaeology, University of York, Wentworth Way, York, UK, Y010 5DD - krista.mcgrath@york.ac.uk

e. Centre d'Écologie Fonctionnelle et Évolutive, UMR5175 (CNRS-Université de Montpellier-UPVM-EPHE), 1919 route de Mende, FR-34293 Montpellier cedex 5 -Ana.rodrigues@cefe.cnrs.fr; Anne.charpentier@cefe.cnrs.fr

\section{PALEO 30 | t. 1}

DÉCEMBRE 2019

PAGES 230 À 242

KEY-WORDS Bone tool, collagen peptide mass fingerprinting, Gray Whale (Eschrichtius robustus), La Madeleine, Magdalenian, projectile point.
The Cetacean bone artifact described in this paper is the result of excavations carried out in La Madeleine (Tursac, Dordogne) under the direction of D. Peyrony, between 1910-1913. It was discovered in the middle layer ("couche moyenne") of the stratigraphy described by Capitan and Peyrony and subsequently attributed to the "Magdalenian V" by H. Breuil (i.e the beginning of the Upper Magdalenian). This layer corresponds to layers C25 to C20 of the stratigraphy established later by J.-M. Bouvier. Two radiocarbon dates are currently available (C21: $12750 \pm 240$ BP, Ly 920; and C25: $13070 \pm 190$ BP, Ly 921). The artifact was recently identified as Cetacean bone during an integrated study of the bones and reindeer antlers kept at the Musée National de Préhistoire (Peyrony and Bouvier collections). It is a fully worked object, elongated in shape (129 X $13.2 \times 12.8 \mathrm{~mm} ; 18.6 \mathrm{~g}$ ) with straight outline and profile, a circular cross-section and parallel sides. It is interpreted as a mesio-proximal fragment of projectile point. Collagen peptide mass fingerprinting (PMF) was applied to taxonomically identify the bone artefact, as a part of the PaleoCet project. Also known as ZooMS, collagen PMF discriminates taxonomic groups based on differences in the collagen protein sequence observed through Matrix-assisted laser desorption/ionization time-of-flight (MALDI-TOF) mass spectrometry. The bone subsamples from the exterior and interior of the artifact produced similar MALDI-TOF spectra, both of which could be confidently identified as gray whale (Eschrichtius robustus). The artifact from La Madeleine is the first evidence of the presence of this species in Atlantic waters at the end of MIS2, suggesting continuity between the Pleistocene and Holocene populations of this species. Moreover, to our knowledge, this gray whale bone artifact represents the oldest identified gray whale in an archaeological context, thus first witness of the millennia-old interactions between humans and this highly coastal whale species. The manufacturing of the La Madeleine artifact on the Basque coast, followed by its circulation through the western Pyrenees and then towards the north at the east of Landes and Gironde up to Périgord (a travel distance of roughly $350 \mathrm{~km}$ ), might be the most plausible route taken by this artifact to reach La Madeleine. 
Une baleine grise dans le Périgord magdalénien : identification taxinomique d'une pointe de projectile en os de La Madeleine (Dordogne, France) par empreinte peptidique de masse du collagène.

L'artefact en os de cétacé décrit dans cet article provient des fouilles effectuées entre 1910 et 1913 à

La Madeleine (Tursac, Dordogne) sous la direction de D. Peyrony. Il a été découvert dans la couche moyenne de la stratigraphie décrite par Capitan et Peyrony («Magdalenien V» de H. Breuil, c'est-à-dire le début du Magdalénien supérieur), et qui correspond aux couches C25 à C20 de la stratigraphie établie ultérieurement par J.-M. Bouvier. Deux dates radiocarbone sont actuellement disponibles (C21: $12750 \pm 240$ BP, Ly 920 ; et C25: 13070 士 190 BP, Ly 921). La pièce a récemment été identifiée comme os de cétacé lors d'une étude intégrée des os et bois de rennes conservés au Musée national de Préhistoire (collections Peyrony et Bouvier). Il s'agit d'un objet entièrement façonné, de forme allongée (longueur X largeur X épaisseur : 129 X 13,2 X 12,8 mm ; masse 18,6 g) avec un contour et un profil droits, une section circulaire et des bords parallèles. Il est interprété comme un fragment mésio-proximal de pointe de projectile. Dans le cadre du projet PaleoCet, l'identification taxinomique de l'artefact osseux a fait l'objet d'une empreinte peptidique de masse de collagène (PMF). Aussi connu sous le nom de ZooMS, le collagène PMF discrimine les groupes taxinomiques en fonction des différences dans la séquence protéique du collagène observées par spectrométrie de masse MALDI-TOF. Les sous-échantillons osseux de l'extérieur et de l'intérieur de l'objet ont produit des spectres MALDI-TOF similaires, que l'on peut rapporter à la baleine grise (Eschrichtius robustus). La pièce de La Madeleine est la première preuve de la présence de cette espèce dans les eaux atlantiques à la fin du MIS2, ce qui suggère une continuité entre les populations pléistocènes et holocènes de cette espèce. Elle constitue la plus ancienne trace de baleine grise identifiée en contexte archéologique, et est donc le plus ancien indice des interactions millénaires entre les humains et cette espèce de baleine très côtière. Une fabrication sur la côte basque, puis une circulation à travers les Pyrénées occidentales, le nord-est des Landes et la Gironde, jusqu'au Périgord (environ $350 \mathrm{~km}$ de trajet), pourrait être la voie la plus plausible suivie par la pièce de La Madeleine.

\section{INTRODUCTION}

Discovered in 1863 by E. Lartet and H. Christy, who carried out the first excavations there (1863-1865), the rockshelter of La Madeleine (Tursac, Dordogne, France; fig. 1) was the subject of various archaeological field projects (E. Massénat and P. Girod in 1895; E. Rivière in 1901) before D. Peyrony conducted methodical archaeological investigations there between 1910 and 1913 (Capitan and Peyrony 1928). The chronological (four radiocarbon dates) and environmental framework were subsequently described as field work was carried out between 1967 and 1983 under the direction of J.-M. Bouvier (Bouvier 1977, 1979).

The historical importance of La Madeleine goes well beyond the important archaeological assemblages recovered at the end of each excavation and now scattered in various museums around the world (Bouvier 1977: 8082; Mémoire 1990). La Madeleine has been the eponymous site of the Magdalenian culture since 1889, and the bone industries from the Peyrony excavations served as a basis for H. Breuil (1912) to define the middle (IV) and upper (V and $\mathrm{VI}$ ) stages of the Magdalenian.

During an integrated study of the bones and reindeer antlers kept at the Musée national de Préhistoire (Peyrony and Bouvier collections; Fontana 2017 and L. Fontana and F.-X. Chauvière, work in progress), the attention of one of us (F.-X. C.) was drawn to the object described in this article. The bone structure of this fragmentary projectile point, found classified among the shaped reindeer antlers, strongly resembled that of Cetacean bones seen in the Magdalenian series of Isturitz (Saint-Martin-d'Arberoue and Isturitz, Pyrénées-Atlantiques, France; collections from the Passemard and Saint-Périer excavations at the Musée d'archéologie nationale) and Duruthy (Sorde-l'Abbaye, Landes, France; collections from the Arambourou excavations at the Abbaye d'Arthous). This macroscopic identification would then be confirmed by J.-M. Pétillon and further clarified by physical-chemical analyses (Pétillon and Chauvière 2019 and see below).

Given the unprecedented nature of this taxonomic determination and the full development of current research on the exploitation of marine mammals in the Paleolithic period, it seemed essential to include an analysis of this object from La Madeleine. First, we will review studies on the exploitation of Cetaceans in the European Paleolithic. The artifact is then described in detail in all its technical and functional dimensions as well as from the point of view of its anatomical and above all specific provenance. We then report the results of biomolecular analyses to identify the species of Cetacean used to construct the artifact, and discuss the implications of the artifact within the framework of the recent Paleolithic
MOTS-CLÉS Industrie osseuse, analyse Zooms, Baleine grise (Eschrichtius robustus), La Madeleine, Magdalénien, pointe de projectile. 


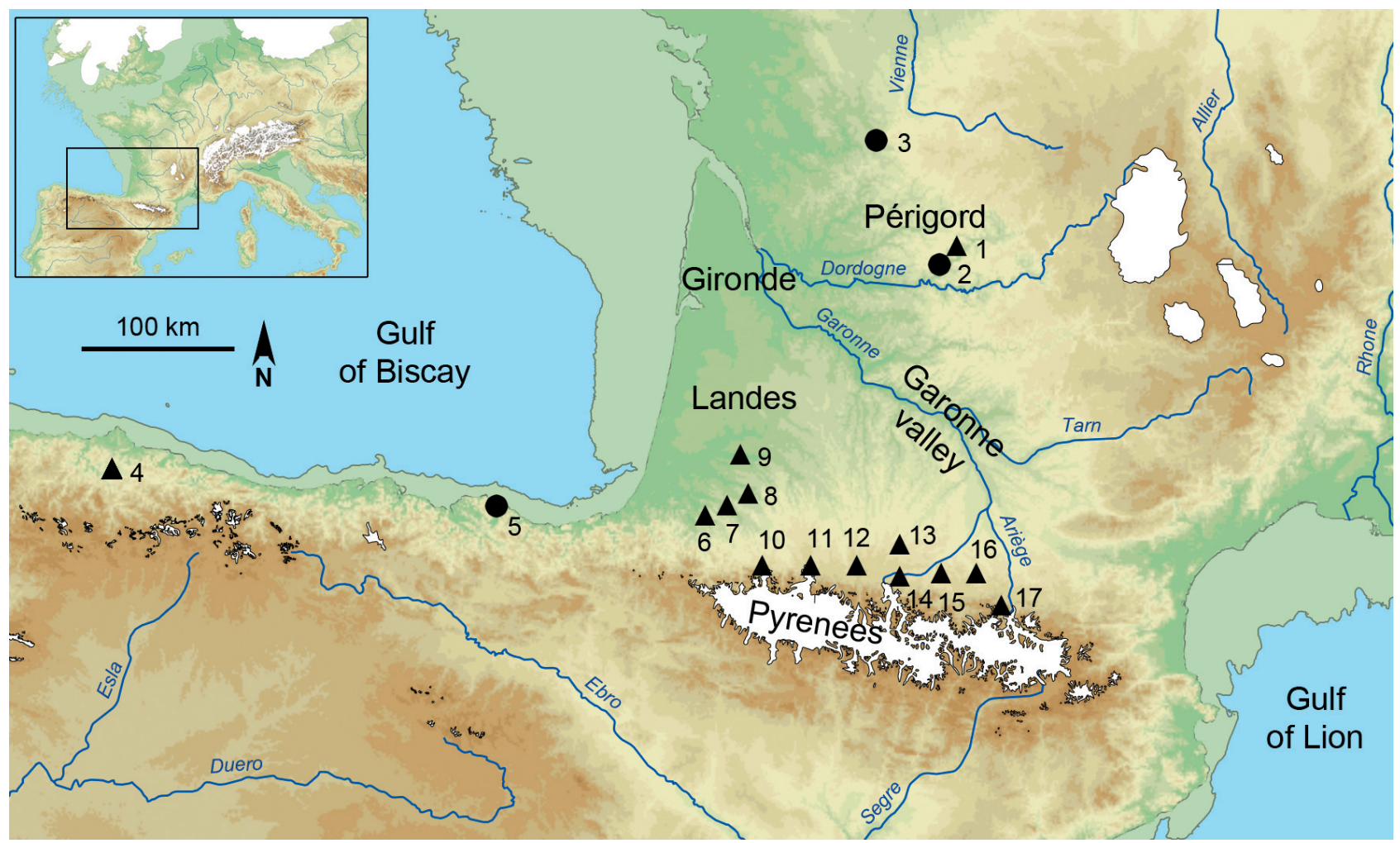

- FIGURE 1 -

Sites and geographic names mentioned in the text. Triangles: sites that yielded objects made of whale bone; circles: other sites. 1: La Madeleine; 2: Laugerie-Basse; 3: Montgaudier; 4: Las Caldas; 5: Santa Catalina; 6: Isturitz; 7: Bourrouilla; 8: Duruthy; 9: Brassempouy; 10: Saint-Michel and Espalungue; 11: Espélugues; 12: Lortet; 13: Harpons; 14: Gourdan; 15: Tuc d'Audoubert; 16: Mas d'Azil; 17: La Vache. Not on map: Nerja, Andernach-Martinsberg. Map of Europe during the Last Glacial Maximum (maximum sea level recession at - $120 \mathrm{~m}$, maximum extension of glaciers; map A. Sécher after data from Ehlers and Gibbard 2004; Farr et al. 2007; Becker et al. 2015; Zickel et al. 2016).
Sites et zones géographiques mentionnés dans le texte. Triangles: sites qui ont livré des objets en os de baleine; cercles: autres sites. 1 : La Madeleine, 2: Laugerie-Basse ; 3 : Montgaudier ; 4 : Las Caldas ; 5 : Santa Catalina ; 6 : Isturitz; 7: Bourrouilla ; 8: Duruthy ; 9 : Brassempouy ; 10 : Saint-Michel et Espalungue ; 11 : Espélugues ; 12 : Lortet ; 13 : Harpons ; 14 : Gourdan ; 15 : Tuc d'Audoubert ; 16: Mas d'Azil; 17 : La Vache. Hors carte: Nerja, Andernach-Martinsberg. Carte de l'Europe durant le dernier maximum glaciaire (recul maximal du niveau de la mer à -120 m, extension maximale des glaciers ; carte A. Sécher d'après des données d'Ehlers et Gibbard 2004 ; Farr et al. 2007 ; Becker et al. 2015 ; Zickel et al. 2016).

\section{1 | THE EXPLOITATION OF CETACEANS \\ IN THE EUROPEAN PALEOLITHIC}

\section{1 | History of research}

For decades, the exploitation of seashore resources by paleolithic hunter-gatherers in Western Europe has received little academic attention. L. G. Straus and G. A. Clark were among the first, in the 1970s and the 1980s, to support the hypothesis that this exploitation became progressively more intense over the course of the Upper Paleolithic (Straus and Clark 1986). In later years, in France, the work of Y. Taborin stressed the importance of marine shells among Paleolithic personal ornaments (Taborin 1993), while two seminal papers addressed the issues of the exploitation of seals and the use of Cetacean teeth (Sonneville-Bordes and Laurent 1983; Poplin 1983), and the first review papers on the importance of the seashore in the Paleolithic began to appear (Cleyet-Merle and Madelaine 1995; Serangeli 2002, 2003). However, it is mostly from the 2000s on, in the wake of a seminal article (Erlandson 2001), that research on this topic intensified and led to an abundance of new data, most importantly

from sites in the Iberian Peninsula (among many others: Corchón et al. 2008; Álvarez-Fernández 2011; Haws et al. 2011; Fano et al. 2013; Berganza and Arribas 2014; etc.).

Despite this renewed interest, the currently available evidence demonstrates that the exploitation of marine resources in the Middle Paleolithic and the Early Upper Paleolithic (Aurignacian) was still sporadic, or occasional at best (Álvarez-Fernández 2015). A slight intensification is perceptible in the Middle Upper Paleolithic (Gravettian and Solutrean), at least in certain regions such as the Cantabrian coast where the exploitation of mollusksmostly Patella vulgata-becomes more frequent (ÁlvarezFernández and Fernández-García 2011; Castaños and Álvarez-Fernández 2012). The bulk of the Paleolithic evidence, however, comes from the Late and Final Upper Paleolithic, corresponding to the Magdalenian and subsequent cultures. This evidence is particularly dense around the Gulf of Biscay (review in Pétillon 2016a) and in southernmost Iberia (e.g., Morales-Pérez et al. 2019), suggesting the existence of a true coastal economy. In these contexts, besides the exploitation of marine mollusks, fish and birds, the presence of sea mammals in the economic and symbolic worlds is documented through 
remains and depictions of seals and Cetaceans (review in Pétillon 2018). Remains of Cetaceans are observed in the form of isolated teeth (sometimes carved and/or pierced), rarely bones (at Santa Catalina and Nerja), and fragments of whale barnacles (at Las Caldas and Nerja: these crustaceans are commonly found embedded in the skin of large Cetaceans and their presence indicates the transport of whale skin, blubber and perhaps meat from the coast to the site).

It is within this research context that a number of objects made of whale bone were identified in the bone industry of several Magdalenian sites. The use of this raw material was first acknowledged by F. Poplin and one of the present authors (J.-M. P.) at the site of Isturitz, in the Middle and Upper Magdalenian layers (Pétillon 2008). In the following years, several other specimens were identified in sites close to Isturitz: Saint-Michel d'Arudy (Pujol 2009), Brassempouy (Lefebvre 2014), and Duruthy (F.-X. C. and M. Dachary, pers. obs.). Subsequently, a systematic review of bone industry assemblages from the Magdalenian sites of the northern Pyrenees increased the number of objects to 109 and the number of sites to 12 (Isturitz, Duruthy, Brassempouy, Saint-Michel, Espalungue, Espélugues, Lortet, Harpons, Gourdan, Le Tuc d'Auboubert, Le Mas d'Azil, La Vache: Pétillon 2013). Very few objects of this type were found during recent excavations, and most of them are from ancient collections, for which few investigations had been made for Cetacean materials. The identification was based on macroscopic criteria (see below) but was also backed up by micro PIXE/PIGE analysis (Müller and Reiche 2011). Although they are sufficient for the generic identification of whale bone, these criteria do not allow us to identify either the species or the anatomical element exploited.

The large majority of the objects currently identified are related to weaponry: projectile points and foreshafts represent 74 of the 88 objects for which a typological attribution could be suggested, the others being wedges $(n=9)$, half-round rods $(n=2)$ or other types of finished objects ( $n=3$; Pétillon 2013). The choice of whale bone as a material for the manufacture of projectile heads can have several reasons. The most obvious is that these bones can be used to manufacture objects of very large dimensions (length, but also caliber, i.e. width/thickness). But it can also be noted that the impact resistance of whale bone, while not being as high as that of antler, is above that of most land mammal bones (see Margaris 2014 and references therein).

\section{2 | Geographical and chronological distribution}

The northern Pyrenean range is so far the only region in which the Magdalenian assemblages of osseous industry have been systematically investigated (with a few exceptions) in order to identify objects made of whale bone. Three quarters of these objects were shown to be concentrated in the Western Pyrenees, while the Central Pyrenees yielded the remaining 25\% and none was found in the eastern part of the range (fig.1). This contrasted distribution is not a function of the relative abundance of worked bone assemblages, and it led to the hypothesis that the Atlantic Coast-the current Basque seashore-was the most likely origin of the bone material exploited, even if the putative seashore sites are of course no longer accessible today (Pétillon 2013). Outside the Pyrenean region, discoveries are much sparser: only the object from Andernach-Martinsberg (Langley and Street 2013), and one from Las Caldas (Corchón and Ortega 2017: 364), have been published.

Most objects made of whale bone are from Middle and Upper Magdalenian contexts. The associated $14 \mathrm{C}$ dates range between ca. 17500 and $15000 \mathrm{cal} \mathrm{BP}$, which corresponds to the late part of the Middle Magdalenian and the early part of the Upper Magdalenian; the typology of the objects is compatible with this attribution (Pétillon 2013). Objects made of whale bone attributed to earlier periods are very few, often unpublished, and their identification is sometimes uncertain. N. Goutas (2008: 49) mentions two objects made of whale bone from the Gravettian layers of Isturitz, but the micro PIXE/PIGE analysis of one of these objects did not confirm its identification as whale bone (Müller and Reiche 2011). Furthermore, no object made of whale bone has been directly radiocarbon-dated so far, and the dating of this material poses specific problems: the apparent age ("reservoir age") of the Gulf of Biscay in the Magdalenian has not been precisely quantified; and the (theoretically possible) use of whale bones originating from individuals that had been stranded significantly earlier might add a further bias (for similar problems in other contexts see for example: Nelson and McGhee 2002; Friesen and Arnold 2008; Marchand et al. 2009).

\section{3 | Recent developments: the PaleoCet project}

The recurrent presence of evidence linked to the exploitation of whales suggests that the abundant resource represented by large Cetaceans might have been one of the major incentives for the intensification of the exploitation of the seashore in the Middle and Upper Magdalenian. Nevertheless, several limitations in our knowledge of whale exploitation prevent us from testing this hypothesis: none of the remains is identified to species level, which means that we have no idea of the range of whale taxa exploited by the Magdalenian foragers, and thus of their ecology and behavior, which can be markedly different from one species to another (Rodrigues et al. 2016; Bernal-Casasola et al. 2016); the chronology of the production and diffusion of whale products remains imprecise; and a systematic search for whale-bone objects outside the northern Pyrenees has not been undertaken, which means that we do not know if this production was a local phenomenon or part of a widely shared technical package.

The PaleoCet project was devised in order to overcome these limitations. Scheduled from 2019 to 2021, funded by the Agence nationale de la recherche and directed by J.-M. Pétillon and A. Zazzo, it is a joint project between the UMRs Traces (Toulouse) and AASPE (Paris), and includes collaborations with UMR Cefe (Montpellier), the University of British Columbia (Vancouver) and the University of York. It will include the taxonomic identification of a large number of Magdalenian whale remains through collagen peptide mass fingerprinting (see below); the direct radiocarbon dating of these remains with the ECHoMICADAS (Environnement, Climat et Homme, MIni CArbon Dating System, installed at Gif-sur-Yvette since 
2017), which makes it possible to drastically reduce sample sizes (Synal 2013; Synal et al. 2007; Cersoy et al. 2017a, 2017b), and accompanied by a specific protocol to quantify the local reservoir effect; and the investigation of collections of bone industry outside the Pyrenees to assess the presence of worked bone remains. The object presented in this paper was identified and analyzed as a part of this project.

\section{2 | THE BONE PROJECTILE POINT \\ OF LA MADELEINE}

\section{1 | Stratigraphic and cultural context}

The Cetacean bone artifact, the description of which will follow, is the result of excavations carried out under the direction of D. Peyrony. It bears the inscription «la mad. $m$. V». It was therefore discovered in the middle layer ("couche moyenne") of the stratigraphy described by Capitan and Peyrony (1928: 63-69) and subsequently attributed to the "Magdalenian V" by H. Breuil (1912). This layer was interposed between the upper and lower layers of the rockshelter ("couches inférieure et supérieure)", which refer respectively to the "Magdalenian IV" and "Magdalenian VI" of Breuil's classification (1912).

The middle layer corresponds to layers C25 to C20 of the stratigraphy established by J.-M. Bouvier (Fontana, 2017: 350). Two radiocarbon dates are currently available (C21: $12750 \pm 240$ BP, Ly 920; and C25: $13070 \pm 190$ BP, Ly 921; Bouvier 1979: 439).

Capitan and Peyrony do not mention this artifact in the chapter concerning the bone industry found in the middle layer (op. cit: 65-69). They report the presence of barbed implements (harpoons with a single row of barbs, tridents), double bevelled projectile points, some conicocylindrical based and some single-bevelled. They also note the presence of perforated batons, spearthrowers and half-round rods. The assemblage (1,227 pieces) was one of the subjects of a technical analysis of manufacturing techniques in L. Braëm's Ph. D. Dissertation (Braëm 2008: 168-174 and following; Braëm-Villesuzanne 2016). In addition, there are engraved and sculpted pieces of portable art and ornaments (Capitan and Peyrony, op. cit.: 71-78; Taborin 1993 ; Vanhaeren and d'Errico 2001).

\section{2 | Description and function}

The artifact is in a very good state of preservation (fig. 2). It is a fully worked object, elongated in shape, with straight outline and profile, a circular cross-section and parallel sides. Its maximum dimensions are $129 \times 13.2 \times 12.8 \mathrm{~mm}$ and it weights $18.6 \mathrm{~g}$. One of its extremities, considered as distal (see below), is fractured. The proximal part is conical in shape, slightly flat, with a blunt end.

The initial identification of the raw material was based on the macroscopic observation of the characteristics of the bony surface. This surface shows indeed a porous aspect which is very different from that of the spongy tissue characteristic of land mammal bones or antler: its structure is intermediate between that of compact and cancellous bone, and could be described as compact bone enclosing relatively wide and sparse trabeculae. The distal fracture of the artifact could have provided an opportunity to directly view these pores in section, but the fracture plane is incrusted with a sediment that makes this examination impossible. The porosity is rather evenly distributed along the whole length and thickness of the artifact: although the pores are denser on one of the sides (third view from the left on fig. 2), there is no clear-cut opposition between a "spongy" side and a "compact" one-which, here again, differs from the usual characteristics of both land mammal bone and antler. Such a structure is, however, typical of the bones of Cetaceans (Margaris 2006, 2014): these bones have no medullary cavity and, although surrounded by a cortical shell, are mostly composed of cancellous tissue (Felts and Spurrell 1965; Buffrénil and Schoevaert 1988; CampbellMalone 2007). This structure is usually interpreted as a specific adaptation to buoyancy in deep water (Taylor 2000; Ricqlès and Buffrénil 2001; Gray et al. 2007). The small size of the object and its degree of transformation prevents us from identifying the anatomical element from which the bone blank was taken.

On such a porous material, traces of working are usually difficult to distinguish, and this object is no exception. The techniques of blank production cannot be identified: no trace of this early stage of manufacture is visible on the artifact. It can be assumed, however, that the shaping of the object was done by scraping, as the aspect of the surface is not compatible with what would have resulted from shaping by grinding. The object shows no surface features such as decoration, striations, longitudinal grooves, etc.

The extremity of the artifact displays a step-terminating beveled break. This morphology shows that the fracture is not post-depositional but was the result of forceful bending during use. This type of damage is compatible with use as a projectile point, but also with other functions involving strong longitudinal constraints (e.g., wedges: see discussion and references in Pétillon et al. 2016a). However, the extremity opposite the fracture shows no macroscopic usewear traces, and its shape is similar to that of points with massive base known elsewhere in the Magdalenian (see Pétillon 2016b and references therein). A typological identification as a mesial-proximal fragment of projectile point is thus the most likely hypothesis. According to a classic model (Chadelle et al. 1991), we can suppose that this point was broken in the field, that the mesio-proximal fragment was brought to the site still attached to a projectile shaft, and was then removed from its haft and discarded on site. The width and thickness of the artifact, ca. $13 \mathrm{~mm}$, clearly hint at a projectile of large caliber, in the "spear" size range (as opposed to arrows: Cattelain 1997; Pétillon et al. 2011: 1273).

In the Magdalenian sites of the northern Pyrenean range, the points with massive base made of whale bone are found in contexts dating to the second half of the Middle Magdalenian rather than the beginning of the Upper Magdalenian (Pétillon 2008, 2013). This typo-chronological argument suggests that the artifact from La Madeleine could be slightly older than what its stratigraphic attribution indicates (in Breuil's terms: "Magdalenian IV" rather than "Magdalenian V"?). 


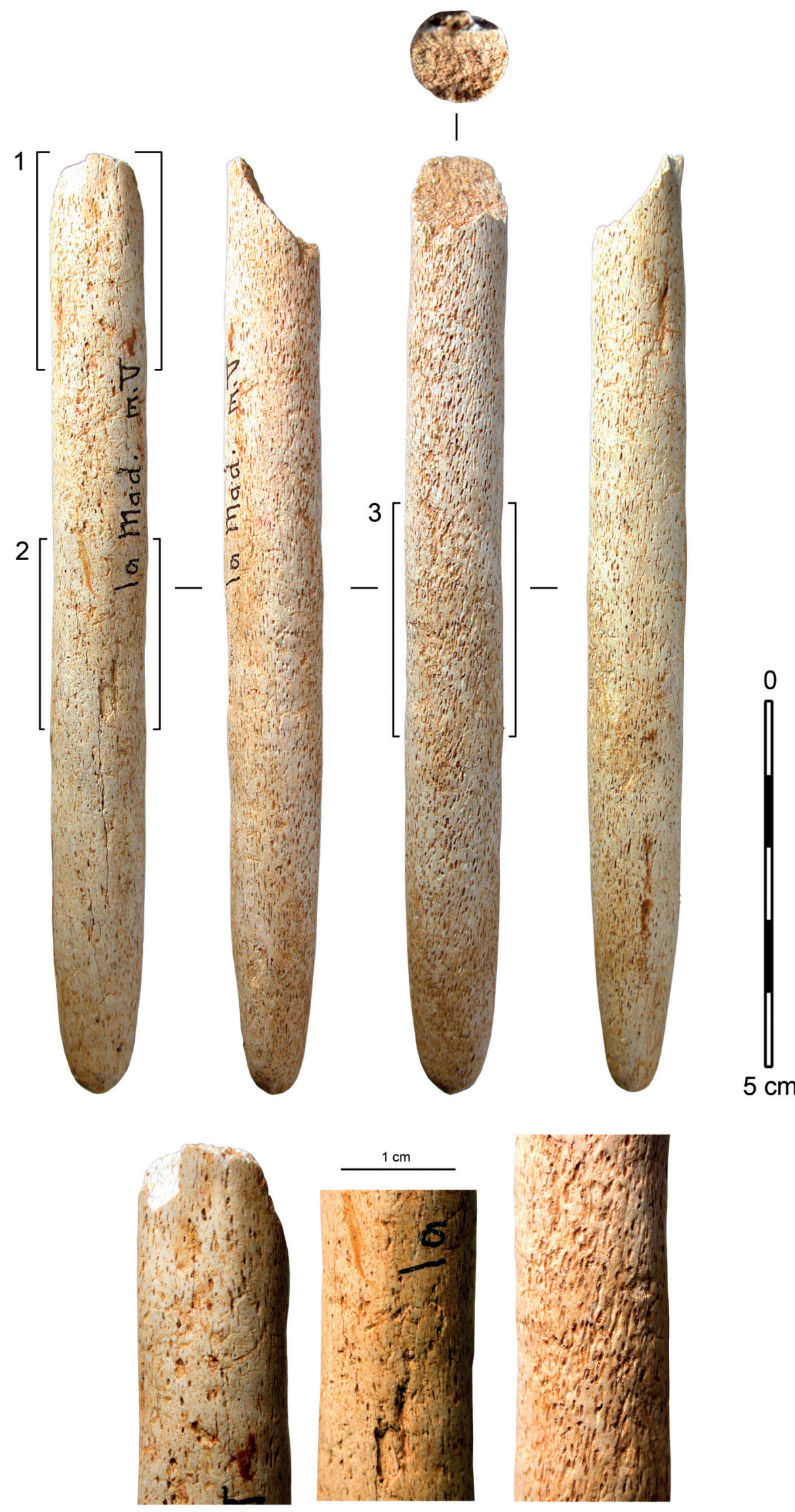

\section{FIGURE 2}

Whale-bone artifact from La Madeleine "M. V", Peyrony collection, Musée national de préhistoire, and details of the bony surface. Pictures J.-M. Pétillon.

Pointe de projectile en os de baleine grise (Eschrichtius robustus) de La Madeleine «M. V》, collection Peyrony, Musée national de préhistoire; détails de la surface osseuse. Clichés I.-M. Pétillon. 


\section{3 | Specific identification}

Collagen peptide mass fingerprinting (PMF) was applied to taxonomically identify the bone artifact. Also known as ZooMS (zooarcheology by mass spectrometry), collagen PMF discriminates taxonomic groups based on differences in the collagen protein sequence observed through Matrixassisted laser desorption/ionization time-of-flight (MALDITOF) mass spectrometry (Collins et al. 2010; Buckley et al. 2014).

In accordance with the routine procedure established in the PaleoCet project, a photogrammetric survey of the object was carried out before any sampling took place. The data necessary to create a 3D model of the artifact in its complete state will thus be archived, both in the project's database and at the museum, in order to keep a record of the artifact's morphology before sampling for conservation purpose. The object was photographed using a Nikon D5500 with a Nikon $60 \mathrm{~mm}$ lens. This camera generates pictures of 24 megapixels ( $6 \mathrm{k} \times 4 \mathrm{k})$. The pictures are kept in raw format in order to avoid any degradation through filtering or compression. The object was photographed on a revolving plate in a light tent lit by two lamps. A large number of pictures were taken at different angles and at least twice: a "front side" series and a "back side" series. The object can thus be reconstructed in its entirety, without a "hidden side".

Sampling was done at the Musée national de préhistoire on March 28, 2019, using a Proxxon Colt 2 pocket drill equipped with a metal bit $2 \mathrm{~mm}$ in diameter. The distal fracture plane was selected as sampling spot and the artifact was drilled longitudinally to extract a powder sample while keeping the sampling as discreet as possible, especially since the object was intended for display in the exhibition "Animaux rares, gibiers inattendus. Reflets de la biodiversité". ZooMS analysis typically requires ca. 10$30 \mathrm{mg}$ of bone sampling. In this case, in order to detect and avoid any contamination that might be present on the surface of the artifact, the bone powder sampled from the surface of the artifact (approximately $10 \mathrm{mg}$ ) was separated from the one sampled from the interior (approximately $24 \mathrm{mg}$ ).

The two subsamples were prepared and analyzed at the BioArCh centre, University of York following the methods described in Evans et al. (2016). The two sub-samples of bone powder were demineralized using 0.6 M hydrochloric acid. The collagen was gelatinized in $100 \mu \mathrm{l}$ of $50 \mathrm{mM}$ ammonium bicarbonate at $65^{\circ} \mathrm{C}$ for $1 \mathrm{~h}$, and $50 \mu \mathrm{l}$ of the supernatant was then incubated overnight with $0.4 \mu \mathrm{g}$ of trypsin at $37^{\circ} \mathrm{C}$. The solution was then acidified to $0.1 \%$ trifluoroacetic acid to deactivate the trypsin, and purified using a $100 \mu \mathrm{l}$ C18 resin ZipTip pipette tip (EMD Millipore). Collagen from both samples was spotted in triplicate using a matrix of $\alpha$-cyanno-4-hydroxycinnamic acid along with calibration standards on a 384-spot MALDI target plate, and run on a Bruker ultraflex III MALDI TOF/TOF mass spectrometer at the University of York. The mMass software (Strohalm et al. 2008) was used to average spectra replicates from each subsample, which were then compared to the list of $\mathrm{m} / \mathrm{z}$ markers for marine mammals presented in Kirby et al. (2013), Buckley et al. (2014) and Hufthammer et al. (2018), in order to taxonomically identify the species used as raw material for the artifact.

The bone subsamples from the exterior and interior of the artifact produced similar MALDI-TOF spectra, both of which could be confidently identified as gray whale (Eschrichtius robustus), based on gray whale specific markers presented in Kirby et al. (2013) and Hufthammer et al. (2018), specifically, the presence of diagnostic collagen peptide $F$ at 2899 (fig. 3).

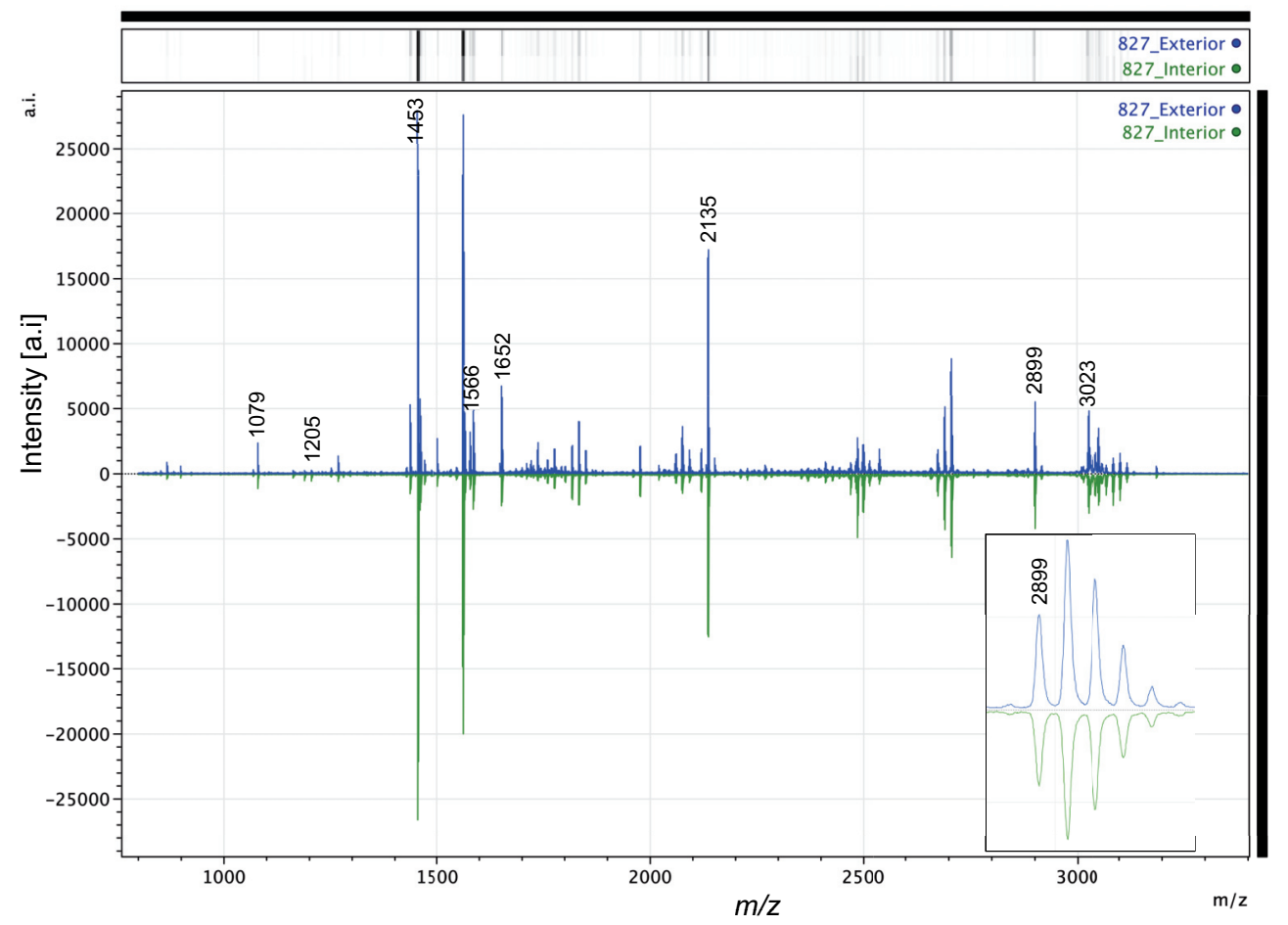

\section{FIGURE 3}

MALDI-ToF spectra for external (top) and internal (bottom) subsamples of the artifact, labelled with taxonomically informative peaks presented in Kirby et al. (2013), Buckley et al. (2014); inset displays close-up of the gray whale diagnostic Peptide F at m/z 2899. a.i. = absolute intensity; $\mathrm{m} / \mathrm{z}=$ mass-to-charge ratio.

Spectre MALDI-ToF des sous-échantillons externes (en haut) et internes (en bas) de l'objet, marqués par des pics taxonomiques caractéristiques présentés dans Kirby et al. (2013), Buckley et al. (2014); l'encadré montre un gros plan du Peptide $F$ diagnostique pour la baleine grise au $\mathrm{m} / \mathrm{z}$ 2899. a.i. = intensité absolue $; \mathrm{m} / \mathrm{z}$ = ratio masse/charge. 


\section{3 | DISCUSSION}

This study further highlights utility of Zooms to taxonomically identify worked bone artifact assemblages, dating back to the Upper Paleolithic. Previous research successfully applied ZooMS to reveal raw material selection and manufacture strategies of Medieval bone and antler combs from Scandinavia (Von Holstein et al. 2014; Brandt et al. 2018), Iroquois bone points from Eastern North America (McGrath et al. 2019), and bone tools from the North African Later Stone Age cave site of Taforalt (Desmond et al. 2018). These combined studies highlight the myriad advantages of ZooMS when working with highly modified, morphologically indistinguishable artifacts. Unlike more conventional DNA 'barcoding approaches', which require some prior knowledge of species in order to design appropriate primers, ZooMS can be applied to highly fragmented non-diagnostic bone without any prior taxonomic knowledge. Moreover, ZooMS targets collagen, which has the potential to survive at least 10 times longer than DNA, increasing the likelihood of analytical success (Welker et al. 2015), especially for minute samples such as those frequently taken from culturally significant items. ZooMS requires extremely small sample sizes (frequently $>5-10 \mathrm{mg}$ of bone) and recent studies have indicated that sufficient collagen may be recovered using a non-destructive ammonium bicarbonate buffer (van Doorn et al. 2011), by gentle rubbing with an eraser (Fiddyment et al. 2015) or through the analysis of artifact storage bags (McGrath et al. 2019) which can enable artifacts of high cultural value to be sampled non-invasively.

Strictly speaking, the geographic origin of this bone cannot be ascertained, but certain assumptions can be made. A Mediterranean origin cannot be ruled out, and would imply travel distances ca. $400 \mathrm{~km}$ given the recession of the coast in the Gulf of Lion at that time. However, the distribution of the other whale-bone objects known today from Magdalenian sites points to an Atlantic origin (Pétillon 2013); and this context is an argument in favor of a similar origin for the artifact from La Madeleine. In this perspective, in the Upper Paleolithic the shortest route from the Atlantic seashore to La Madeleine shelter would have been from the coast of present-day Gironde and Landes, at orthodromic distances ca. $240 \mathrm{~km}$ given the recession of the sea level (fig. 1). However, the likely date of the La Madeleine object is either the Recent Middle Magdalenian or the Early Upper Magdalenian, ca. 17.5-15 cal ka BP (a period which is also that of the diffusion of whalebone objects in the Pyrenees: Pétillon 2013); and recent studies support the hypothesis that, at that period, the Gironde was devoid of Magdalenian sites, and this region was probably largely deserted because of the harsh conditions of the Heinrich Stadial 1a (Barshay-Szmidt et al. 2016; Naughton et al. 2016; Pétillon et al. 2016b). The same holds true for the Landes sandy region, which has been repulsive for human groups during a large part of the Paleolithic because of its desert conditions (Bertran et al. 2013; Sitzia 2014; Sitzia et al. 2015); subsequent research suggests that a similar situation prevailed further east in the Garonne valley (Bruxelles and Jarry 2011). Thus, the shortest route between La Madeleine and the Atlantic coast crosses regions that were very probably barren and inhospitable at these times, and for this reason this route might actually not be the most likely to have been taken by the whale-bone diffusion networks. Conversely, in the western and central part of the northern Pyrenean range are numerous sites dated to that period, a dozen of which yielded objects made of whale bone; and many studies pinpointed evidence of communication between this region and the Magdalenian Périgord (circulation of lithic raw materials, distribution of specific technical and graphic traits, etc.: e.g., Cattelain 2005; Fritz et al. 2007). This is especially true for the Magdalenian assemblages from La Madeleine and Laugerie-Basse shelters, which share many common points with contemporaneous sites in the Pyrenees (e.g., collective 2014; Cattelain and Bellier 2014; Cattelain 2016). The manufacturing of the La Madeleine artifact on the Basque coast, followed by its circulation through the western Pyrenees and then towards the north at the east of Landes and Gironde up to Périgord (a travel distance of roughly $350 \mathrm{~km}$ ), might thus actually be the most plausible route.

Before the determination of this whale-bone artifact in La Madeleine, only shells were used to link this archaeological site - directly or indirectly - with the Paleolithic coastlines. In the "middle layer" (Magdalenian V) of the stratigraphy described by Capitan and Peyrony, Y. Taborin mentions the presence of Würmian shells, either Atlantic or Mediterranean: several Turitella communis, 1 or 2 Cardium edule (perforated), 1 Pecten maximus or jacobeus (Taborin 1993, pp. 158-159, 432, 485; see also Vanhaeren and Errico, op. cit., p. 206-207).

Irrespective of whether gray whales were actively captured or scavenged from stranded individuals, their coastal ecology means that they must have been well known to coastal communities, which is important to consider when envisioning their place in the Magdalenian cultural world. Contrary to high sea species, which were probably only known from dead or moribund individuals, live gray whales would have been observed from high points in the coastline or as the whales jumped. Gray whales are medium-sized baleen whales (mysticetes) measuring 13$15 \mathrm{~m}$ with a weight ca. 14-35 tons. They are named after the gray-white patches on their dark skin. Anatomically this species - the only living one in the genus Eschrichtiidae is characterized by the absence of dorsal fin; short, whitish baleen plates; and a double blowhole that can produce distinctive heart-shaped blows (Swartz 2014). They are migratory, moving seasonally from cold high-latitude feeding grounds to warmer lower-latitude calving areas. They are coastal in all of these seasons, feeding in low-depth waters, migrating by hugging the coastline, and calving in sheltered low-depth lagoons. Whereas in today's climate the Gulf of Biscay and the Mediterranean would more likely correspond to calving grounds (Rodrigues et al. 2018), it is possible that in the Upper Paleolithic they would have corresponded to feeding grounds. In any case, they would have been conspicuously present at predictable seasons, and they are likely to have been part of the range of animals whose ecology would have been known to Paleolithic hunter-gatherers.

Gray whales today have a strictly North Pacific distribution: they do not seem to have survived in the North Atlantic after the eighteenth century, having probably disappeared due to whaling even if the circumstances of their disappearance remain poorly understood (Rodrigues et al. 2018). Previous evidence of their past presence in the 
North Atlantic dates either to the Holocene or to the middle of MIS3, before 35 cal ka BP, with a gap in-between (Alter et al. 2015; Garrison et al. 2019). Furthermore, molecular analyses revealed little genetic continuity between the late Pleistocene and the Holocene populations: most Atlantic Holocene specimens analyzed by Alter et al. (2015) are genetically closer to Holocene Pacific gray whales than to Pleistocene Atlantic specimens, leading these authors to suggest that the majority of the Atlantic Holocene population were the result of a second colonization event from the Pacific, after warming temperatures, sea-level rise, and decreases in sea ice permitted passage through the Bering Strait (Alter et al., 2015). The artifact from La Madeleine is the first evidence of the presence of this species in Atlantic waters at the end of MIS2, thus supporting instead a continuity between the Pleistocene and the Holocene populations.

\section{4 | CONCLUSION}

Prior to this study, the identification of whale species in the Magdalenian was based almost exclusively on the few teeth remains found in Magdalenian sites and on tentative taxonomic attributions of the rare whale depictions in the Magdalenian cave art and portable art (see review and references in Pétillon 2018). These species include Sperm Whale (teeth from Mas d'Azil and Las Caldas, possible depictions in Bourrouilla, La Vache and Las Caldas), LongFinned Pilot whale (teeth in Las Caldas and possibly in Duruthy, Arambourou collection) and, without any certainty, Beluga whale (possible teeth in Duruthy, Arambourou collection; possible depiction in Las Caldas?) and one species of Right whale (presence of specific whale barnacles at Nerja: Álvarez Fernández et al. 2014). The presence of Gray Whale had been suggested only once, based on the possible identification of small figures on the Montgaudier bâton percé as right whales or gray whales (Robineau 1984; one might add that the same suggestion can be made for the "fish" depicted on the same object). The analysis of the La Madeleine object is thus the first formal identification of this species in the Magdalenian, and in the European Paleolithic altogether. It shows the great potential of the Magdalenian assemblage of whale-bone object as a depository of whale biodiversity at that period, and the relevance of the ZooMS technique to bring that potential to realization.

Finally, this gray whale bone artifact represents (to our knowledge) the oldest identified gray whale in an archaeological context, being thus the oldest evidence of the millennia-long relationship between our two species.

\section{ACKNOWLEDGEMENTS}

We thank the Musée National de Préhistoire for allowing us to study and sample the object presented in this paper. This research was supported by the PaleoCet project (ANR18-CE27-0018-01). We thank the editorial board and two anonymous reviewers for their comments that helped to improve the manuscript.

\section{REFERENCES}

ALTER S.E., MEYER M., POST K., CZECHOWSKI P., GRAVLUND P., GAINES C., ROSENBAUM H.C., KASCHNER K., TURVEY S.T., VAN DER PLICHT J., SHAPIRO B., HOFREITER M. 2015 - Climate impacts on transocean dispersal and habitat in gray whales from the Pleistocene to 2100. Molecular Ecology, 24, p. 1510-1522.

ÁLVAREZ-FERNÁNDEZ E. 2011 - Humans and marine resource interaction reappraised: Archaeofauna remains during the late Pleistocene and Holocene in Cantabrian Spain. Journal of Anthropological Archaeology, 30, p. 327-343.

ÁLVAREZ-FERNÁNDEZ E. 2015 - Marine resource exploitation during the Middle and Early Upper Paleolithic in Europe: Overview of the Available Evidence.P@lethnologie, 5, p. 188-205.

ÁLVAREZ-FERNÁNDEZ E., FERNÁNDEZ-GARCÍA R. 2011 Marine resources exploitation in Cantabrian Spain during the Solutrean: molluscs, fish and sea mammals. Bulletin du musée d'anthropologie préhistorique de Monaco, 51, p. 87-97.

ÁLVAREZ-FERNÁNDEZ E., CARRIOL R.-P., JORDÁ J.F., AURA J.E., AVEZUELA B., BADAL E., CARRIÓN Y., GARCÍA-GUINEA J., MAESTRO A., MORALES J.V., PEREZ G., PEREZ-RIPOLL M., RODRIGO M.J., SCARFF J., VILLALBA M.P., WOOD R. 2014 Occurrence of whale barnacles in Nerja Cave (Málaga, southern Spain): Indirect evidence of whale consumption by humans in the Upper Magdalenian. Quaternary International, 337, p. 163-169.

BARSHAY-SZMIDT C., COSTAMAGNO S., HENRY-GAMBIER D., LAROULANDIE V., PÉTILLON J.-M., BOUDADI-MALIGNE M., KUNTZ D., LANGLAIS M., MALLYE J.-B. 2016 - New extensive focused AMS $14 \mathrm{C}$ dating of the Middle and Upper Magdalenian of the western Aquitaine/Pyrenean region of France (ca. 19-14 Ky cal BP). Proposing a new model for its chronological phases and for the timing of occupation. Quaternary International, 414, p. 62-91.

BECKER D., VERHEUL J., ZICKEL M., WILLMES C. 2015 - LGM paleoenvironment of Europe - Map. CRC806-Database, doi: $10.5880 /$ SFB806.1

BERGANZA GOCHI E., ARRIBAS PASTOR J.L. (Ed.) 2014 - La Cueva de Santa Catalina (Lekeitio, Bizkaia) I - La Intervención Arqueológica: Restos Vegetales, Animales y Humanos. Bilbao, Kobie BAl 4, 377 p.

BERNAL-CASASOLA D., GARDEISEN A., MORGENSTERN P., HORWITZ L., PIQUÉS G., THEODOROPOULOU T., WILKENS B. 2016 - Ancient whale exploitation in the Mediterranean: The archaeological record. Antiquity, 90(352), p. 914-927.

BERTRAN P., SITZIA L., BANKS W.E., BATEMAN M.D., DEMARS P.-Y., HERNANDEZ M., LENOIR M., MERCIER N., PRODEO F. 2013 - The Landes de Gascogne (southwest France): periglacial desert and cultural frontier during the Palaeolithic. Journal of Archaeological Science, 40, p. 2274-2285.

BOUVIER J.-M. 1977 - Un gisement préhistorique : La Madeleine. Périgueux : Fanlac, 86 p. 
BOUVIER J.-M. 1979 - La Madeleine : acquis récents. In : De Sonneville-Bordes, D. (Ed.), La fin des temps glaciaires en Europe. Chronostratigraphie et écologie des cultures du Paléolithique final. Paris : CNRS, p. 435-441.

BRAËM L. 2008 - Approche typologique et technique des ensembles osseux de Laugerie-Basse et de La Madeleine. Aix-en-Provence, Université de Provence, thèse de doctorat, $413 \mathrm{p}$.

BRAËM-VILLESUZANNE L. 2016 - La Madeleine et les abris de Laugerie-Basse : de l'acquisition des bois de renne aux objets d'art mobilier. In : J.- J. Cleyet-Merle, J.- M. Geneste, E.Man-Estier (Dir.), L'art au quotidien - Objets ornés du Paléolithique supérieur, Actes du colloque international, Les Eyzies, 16-20 juin 2014. Paleo, numéro spécial, p. 177-197.

BRANDT L.Ø., HAASE K., COLLINS, MJ. 2018 - Species identification using ZooMS, with reference to the exploitation of animal resources in the Medieval town of Odense. Danish Journal of Archaeology, 7(2), p. 1-15.

BREUIL H. 1912 - Les subdivisions du paléolithique supérieur et leur signification, In : Compte rendu de la XIVe session du Congrès international d'anthropologie et d'archéologie préhistoriques. Kündig : Genève, p. 165-238.

BRUXELLES L., JARRY M. 2011 - Climatic conditions, settlement patterns and cultures in the Paleolithic: the example of the Garonne Valley (southwest France). Journal of Human Evolution, 61, p. 538-548.

BUCKLEY M., FRASER S., HERMAN J., MELTON N. D., MULVILLE J., PÁLSDÓTTIR A. H. 2014 - Species identification of archaeological marine mammals using collagen fingerprinting. Journal of Archaeological Science, 41, p. 631-641.

BUFFRÉNIL V. (de), SCHOEVAERT D. 1988 - On how the periosteal bone of the delphinid humerus becomes cancellous: ontogeny of a histological specialization. Journal of Morphology, 198, p. 149-64.

CAMPBELL-MALONE R. 2007 - Biomechanics of North Atlantic Right Whale: mandibular fracture as a fatal endpoint for blunt vessel-whale collision modeling. Doctoral thesis in biological oceanography, Cambridge/Woods Hole, Massachusetts Institute of Technology/Woods Hole Oceanographic Institution, 257 p.

CAPITAN L., PEYRONY D. 1928 - La Madeleine, son gisement, son industrie, ses œuvres d'art. Publications de l'Institut International d'Anthropologie, 2. Paris : Librairie Nourry, $125 \mathrm{p}$.

CASTAÑOS P., ÁLVAREZ-FERNÁNDEZ E. 2012 - Nuevas aportaciones a las bases de subsistencia de origen animal durante el Gravetiense cantábrico. In : C. de las Heras, J. A. Lasheras, Á. Arrizabalaga, M. de la Rasilla (Eds.), Pensando el Gravetiense: nuevos datos para la región cantábrica en su contexto peninsular y pirenaico, Altamira, Museo de Altamira (Monografías del Museo Nacional y Centro de Investigación de Altamira, 23), p. 313-329.

CATTELAIN P. 1997 - Hunting during the upper Paleolithic: bow, spearthrower, or both? In : H. Knecht, (Ed.), Projectile Technology. New York: Plenum Press (Interdisciplinary contributions to archaeology), p. 213-240.
CATTELAIN P. 2005 - Propulseurs magdaléniens marqueurs culturels régionaux? In : Dujardin, V. (Ed.), Industrie osseuse et parures du Solutréen au Magdalénien en Europe. Paris, Société préhistorique française (Mémoires de la Société préhistorique française, 39), p. 301-317.

CATTELAIN P. 2016 - Les propulseurs de l'Abri de La Madeleine (Dordogne, France). In : J.- J. Cleyet-Merle, J.-M. Geneste, E.Man-Estier (Dir.), L'art au quotidien - Objets ornés du Paléolithique supérieur, Actes du colloque international, Les Eyzies-de-Tayac, 16-20 juin 2014. Paleo, numéro spécial, p. 217-242.

CATTELAIN P., BELLIER C. 2014 - Objets décorés pris sur stylohyoideum. In : Mons, L., Péan, S., Pigeaud, R. (Eds.), Matières d'art: représentations préhistoriques et supports osseux, relations et contraintes; Commission de nomenclature sur l'industrie de l'os préhistorique, cahier XIII, Paris, Errance, p. 91-104.

CERSOY S., ZAZZO A., ROFES J., TRESSET A., ZIRAH S., GAUTHIER C., KALTNECKER E., THIL F., TISNERAT-LABORDE N. 2017a - Radiocarbon dating minute amounts of bone (3$60 \mathrm{mg}$ ) with ECHoMICADAS. Scientific Reports, 7, 7141.

CERSOY S., ZAZZO A., LEBON M., ROFES J., ZIRAH S. 2017b Collagen Extraction and Stable Isotope Analysis of Small Vertebrate Bones: A Comparative Approach. Radiocarbon, 59(3), p. 679-694.

CHADELLE J.-P., GENESTE J.-M., PLISSON H. 1991 - Processus fonctionnels de formation des assemblages technologiques dans les sites du Paléolithique supérieur. Les pointes de projectiles lithiques du Solutréen de la grotte de CombeSaunière (Dordogne, France). In : 25 ans d'études technologiques en préhistoire, XIe Rencontres Internationales d'Archéologie et d'Histoire d'Antibes, 18-1920 octobre 1990. Juan-les-Pins : APDCA, p. 275-287.

CLEYET-MERLE J.-J., MADELAINE S. 1995 - Inland evidence of human sea coast exploitation in Palaeolithic France. In : A. Fischer (Ed.), Man and sea in the Mesolithic: Coastal settlement above and below present sea level. Proceedings of the international symposium (Kalundborg, Denmark, 1993). Oxford: Oxbow books, p. 303-308.

COLLECTIVE 2014 - Grands sites d'art magdalénien. La Madeleine et Laugerie-Basse il y a 15000 ans. Les Eyziesde-Tayac: Musée national de préhistoire, 128 p.

COLLINS M., BUCKLEY M., GRUNDY H., THOMAS-OATES J., WILSON J., VAN DOORN N. 2010 - ZooMS: the collagen barcode and fingerprints. Spectroscopy Europe, 22, 2, p. 610.

CORCHÓN M.S., ORTEGA P. 2017 - Las industrias líticas y óseas (17,000-14,500 BP). Tipología, tecnología y materias primas. In : M.S. Corchón (Ed.), La cueva de Las Caldas (Priorio, Oviedo). Ocupaciones magdalenienses en el valle del Nalón. Salamanca. Ediciones Universidad de Salamanca, p. 247-555. 
CORCHÓN M.S., MATEOS A., ÁLVAREZ-FERNÁNDEZ E., PEÑALVE E., DELCLÒS X., VAN DER MADE J. 2008 - Ressources complémentaires et mobilité dans le Magdalénien cantabrique. Nouvelles données sur les mammifères marins, les crustacés, les mollusques et les roches organogènes de la Grotte de Las Caldas (Asturies, Espagne). L'Anthropologie, 112(2), p. 284-327.

DESMOND A., BARTON N., BOUZOUGGAR A., DOUKA K., FERNANDEZ P., HUMPHREY L., MORALES J., TURNER E., BUCKLEY M. 2018 - ZooMS identification of bone tools from the North African Later Stone Age. Journal of Archaeological Science, 98, p. 149-157.

EHLERS J., GIBBARD P.L. 2004 - Quaternary Glaciations, Extent and Chronology: part I, Europe. Amsterdam: Elsevier, $488 \mathrm{p}$.

ERLANDSON J.M. 2001 - The archaeology of aquatic adaptations: paradigms for a new millennium. Journal of Archaeological Research, 9, p. 287-350.

EVANS S., BRIZ I GODINO I., ÁLVAREZ M., ROWSELL K., COLLIER P., DE GOODALL R. N. P., MULVILLE J., LACROUTS A., COLLINS M.J., SPELLER C. 2016 - Using combined biomolecular methods to explore whale exploitation and social aggregation in hunter-gatherer-fisher society in Tierra del Fuego. Journal of Archaeological Science: Reports, 6, p. 757-767.

FELTS W.J.L., SPURRELL F.A. 1965 - Structural orientation and density in Cetacean humeri. American Journal of Anatomy, 116, p. 171-203.

FANO M.A., GUTIÉRREZ-ZUGASTI F.I., ÁLVAREZ-FERNÁNDEZ E., FERNÁNDEZ-GARCÍA R. 2013 - Late Glacial and Postglacial use of marine resources in the Bay of Biscay, North Spain. In : G.N. Bailey, K. Hardy, A. Camara (Ed.), Shell Energy. Mollusc Shells as Coastal Resources. Oxford: Oxbow books, p. 155-166.

FARR T.G., ROSEN P.A., CARO E., CRIPPEN R., DUREN R., HENSLEY S., KOBRICK M., PALLER M., RODRIGUEZ E., ROTH L., SEAL D., SHAFFER S., SHIMADA J., UMLAND J., WERNER M., OSKIN M., BURBANK D. \& ALSDORF D. 2007 - The Shuttle Radar Topography Mission. Review of Geophysics, 45(2), doi: 10.1029/2005RG000183

FIDDYMENT S., HOLSINGER B., RUZZIER C., DEVINE A., BINOIS A., ALBARELLA U.., FISCHER R., NICHOLS E., CURTIS A., CHEESE E., TEASDALE M.D., CHECKLEY-SCOTT C., MILNER S.J., RUDY K.M., JOHNSON E.J., VNOUČEK J., GARRISON M., MCGRORY S., BRADLEY D.G., COLLINS M.J. 2015 - Animal origin of 13th-century uterine vellum revealed using noninvasive peptide fingerprinting. Proceedings of the National Academy of Sciences of the United States of America, 112 (49), p. 15066-15071.

FONTANA L. 2017 - The four seasons of reindeer: Nonmigrating reindeer in the Dordogne region (France) between 30 and 18k? Data from the Middle and Upper Magdalenian at La Madeleine and methods of seasonality determination. Journal of Archaeological Science: Reports, 12, p. 346-362.
FRIESEN T.M., ARNOLD C.D. 2008 - The timing of the Thule migration: new dates from the western Canadian Arctic. American Antiquity, 73, p. 527-538.

FRITZ C., TOSELLO G., SAUVET G. 2007 - Groupes ethniques, territoires, échanges : la notion de frontière dans l'art magdalénien. In : Cazals, N., González Urquijo, J., Terradas, $X$. (Eds.), Frontières naturelles et frontières culturelles dans les Pyrénées préhistoriques. Barcelone: Museo de Cataluña, p. 165-181.

GARRISON E.G., MORGAN G.S., MCGRATH K., SPELLER C., CHERKINSKY A. 2019 - Recent dating of extinct Atlantic gray whale fossils (Eschrichtius robustus), Georgia Bight and Florida, western Atlantic Ocean. PeerJ, 7, e6381.

GOUTAS N. 2008 - Les pointes d'Isturitz sont-elles toutes des pointes de projectile? Gallia Préhistoire, 50, p. 45-101.

GRAY N.M., KAINEC K., MADAR S., TOMKO L., WOLFE S. 2007 Sink or swim? Bone density as a mechanism for buoyancy control in early Cetaceans. The Anatomical Record, 290, p. 638-653.

HAWS J.A., FUNK C.L., BENEDETTI M.M., BICHO N.F., DANIELS J.M., MINCKLEY T.A., DENNISTON R.F., JERAJ M., GIBAJA J.F., HOCKETT B.S., FORMAN S.L. 2011 - Paleolithic landscapes and seascapes of the west coast of Portugal. In : N.F. Bicho, J.A. Haws, L.G. Davis (Ed.), Trekking the Shore. Changing Coastlines and the Antiquity of Coastal Settlement. New York: Springer, p. 203-246.

HUFTHAMMER A.K., ARNTSEN L., KITCHENER A.C., BUCKLEY M. 2018 - Grey whale (Eschrichtius robustus) in Norwegian waters 2000 years ago. Palaeogeography, Palaeoclimatology, Palaeoecology, 495, p. 42-47.

KIRBY D.P., BUCKLEY M., PROMISE E., TRAUGER S. A., HOLDCRAFT T.R. 2013 - Identification of collagen-based materials in cultural heritage. The Analyst, 138, 17, p. 4849-4858.

LANGLEY M.C., STREET M. 2013 - Long range inland-coastal networks during the Late Magdalenian: Evidence for individual acquisition of marine resources at AndernachMartinsberg, German Central Rhineland. Journal of Human Evolution, 64, p. 457-465.

LEFEBVRE A. 2014 - Les industries osseuses des collections anciennes de Brassempouy, Archéologie des Pyrénées occidentales et des Landes, hors-série 6, p. 57-93.

MARCHAND G., DUPONT C., OBERLIN C., DELQUE-KOLIC E. 2009 - Entre « effet réservoir » et « effet de plateau » : la difficile datation du Mésolithique de Bretagne. In : P. Crombé, M. Van Strydonck, J. Sergant, M. Boudin, M. Bats (Ed.), Chronology and Evolution within the Mesolithic of North-West Europe, Proceedings of an international meeting, Brussels, May 30 - June 12007. Cambridge : Cambridge Scholars Publishing, p. 297-324.

MARGARIS A.V. 2006 - Alutiiq engineering: the mechanics and design of skeletal technologies in Alaska's Kodiak archipelago. Tucson, University of Arizona, Ph.D. Dissertation, 255 p. 
MARGARIS A.V. 2014 - Reconsidering raw material selection: Skeletal technologies and design for durability in subarctic Alaska. Journal of Archaeological Method and Theory, 21, p. 669-695.

MCGRATH K., ROWSELL K., GATES ST-PIERRE C., TEDDER A., FOODY G., ROBERTS C., SPELLER C., COLLINS, M. 2019 - The Identification of Archaeological Bone through NonDestructive ZooMS and the Materiality of Symbolic Expressions: The Example of Iroquoian Bone Projectile Points. Scientific Report (2019)9:11027.

MEMOIRE N. 1990 - De la fouille au musée ou la dispersion des collections durant la préhistoire de la Belle époque. In : Cleyet-Merle et al., Lartet, Breuil, Peyrony et les autres Une histoire de la préhistoire en Aquitaine. Ministère de la culture, Sarlat: Société des Amis du Musée et de la Recherche Archéologique, p. 79-84.

MORALES-PÉREZ J.V., PÉREZ RIPOLL M., JORDÁ PARDO J.F., ÁLVAREZ-FERNÁNDEZ E., MAESTRO GONZÁLEZ A., AURA TORTOSA J.E. 2019 - Mediterranean monk seal hunting in the regional Epipalaeolithic of Southern Iberia. A study of the Nerja Cave site (Málaga, Spain). Quaternary International, 515, p. 80-91.

MÜLLER K., REICHE I. 2011 - Differentiation of archaeological ivory and bone materials by micro-PIXE/PIGE with emphasis on two Upper Palaeolithic key sites: Abri Pataud and Isturitz, France. Journal of Archaeological Science, 38, p. $3234-3243$

NAUGHTON F., SANCHEZ GOÑI M.F., RODRIGUES T., SALGUEIRO E., COSTAS, S., DESPRAT S., DUPRAT J., MICHEL E., ROSSIGNOL L., ZARAGOSI S., VOELKER A.H.L., ABRANTES F. 2016 - Climate variability across the last deglaciation in NW Iberia and its margin. Quaternary International, 414, p. 9-22.

NELSON D.E., McGHEE R. 2002 - Aberrant radiocarbon dates on an Inuit arrowhead. Arctic, 55, p. 345-347.

PÉTILLON J.-M. 2008 - First evidence of a whale-bone industry in the western European Upper Paleolithic: Magdalenian artifacts from Isturitz (Pyrénées-Atlantiques, France). Journal of Human Evolution, 54, p. 720-726.

PÉTILLON J.-M. 2013 - Circulation of whale-bone artifacts in the northern Pyrenees during the Late Upper Paleolithic. Journal of Human Evolution, 65, p. 525-543.

PÉTILLON J.-M. 2016a - Vivre au bord du golfe de Gascogne au Paléolithique supérieur récent : vers un nouveau paradigme / Life on the shore of the Bay of Biscay in the Late Upper Paleolithic: towards a new paradigm. In : C. Dupont and G. Marchand (dir.), Archéologie des chasseurs-cueilleurs maritimes. De la fonction des habitats à l'organisation de l'espace littoral / Archaeology of maritime hunter-gatherers. From settlement function to the organization of the coastal zone. Paris : Société préhistorique française (Séances de la Société préhistorique française, 6), p. 23-36.
PÉTILLON J.-M. 2016b - Technological Evolution of Hunting Implements among Pleistocene Hunter-Gatherers: Osseous Projectile Points in the Middle and Upper Magdalenian (19-14 ky cal BP). Quaternary International, 414, p. 108-134.

PÉTILLON J.-M. 2018 - Échos de l'océan : phoques et baleines en Europe au Paléolithique récent. In : P. Cattelain, M. Gillard, A. Smolderen (dir.), Disparus ? Les mammifères au temps de Cro-Magnon en Europe. Treignes: Cedarc (catalogues d'exposition), p. 335-354.

PÉTILLON J.-M., CHAUVIĖRE F.-X. 2019 - Les mammifères marins. In : C. Cretin et S. Madelaine (Ed.), Animaux rares, gibiers inattendus. Reflets de la biodiversité, catalogue de l'exposition au Musée national de préhistoire. Les Eyziesde-Tayac - Sireuil : Musée national de préhistoire, p. 92-96.

PÉTILLON J.-M., BIGNON O., BODU P., CATTELAIN P., DEBOUT G., LANGLAIS M., LAROULANDIE V., PLISSON H., VALENTIN B. 2011 - Hard core and cutting edge: experimental manufacture and use of Magdalenian composite projectile tips. Journal of Archaeological Science, 38 (6), p. 1266-1283.

PÉTILLON J.-M., PLISSON H., CATTELAIN P. 2016a - Thirty Years of Experimental Research on the Breakage Patterns of Stone Age Osseous Points. Overview, Methodological Problems and Current Perspectives. In : R. Iovita et K. Sano (Ed.), Multidisciplinary approaches to the study of Stone Age weaponry. Springer (Vertebrate Paleobiology and Paleoanthropology Series), p. 47-63.

PÉTILLON J.-M., LAROULANDIE V., COSTAMAGNO S., LANGLAIS M. 2016b - Testing environmental determinants in the cultural evolution of hunter-gatherers: a three-year multidisciplinary project on the occupation of the western Aquitaine basin during the Middle and Upper Magdalenian (19-14 kyr cal BP). Quaternary International, 414, p. 1-8.

POPLIN F. 1983 - La dent de Cachalot sculptée du Mas d'Azil, avec remarques sur les autres restes de cétacés de la Préhistoire française. In : F. Poplin (Ed.), La Faune et l'homme préhistoriques. Paris: Société préhistorique française, p. 81-94.

PUJOL E. 2009 - L'exploitation des matières osseuses chez les Magdaléniens de Saint-Michel d'Arudy (PyrénéesAtlantiques). Paris, Université de Paris 1, Mémoire de master 2, $76 \mathrm{p}$.

RICQLĖS A. de, BUFFRÉNIL V. de 2001 - Bone histology, heterochronies and the return of Tetrapods to life in water: where are we? In : J.M. Mazin et V. de Buffrénil (Ed.), Secondary Adaptation of Tetrapods to Life in Water. München : Friedrich Pfeil Verlag, p. 289-310.

ROBINEAU D. 1984 - Sur les mammifères marins du bâton gravé préhistorique de Montgaudier. L'Anthropologie, 88(4), p. 661-664.

RODRIGUES A.S.L., HORWITZ L., MONSARRAT S., CHARPENTIER A. 2016 - Ancient whale exploitation in the Mediterranean: Species matters. Antiquity, 90(352), p. 928-938. 
RODRIGUES A.S.L, CHARPENTIER A., BERNAL-CASASOLA D., GARDEISEN A., NORES C., PIS MILLÁN J.A., MCGRATH K., SPELLER C.F. 2018 - Forgotten Mediterranean calving grounds of grey and North Atlantic right whales: evidence from Roman archaeological records. Proceedings of the Royal Society B, 285, 20180961.

SERANGELI J. 2002 - La zone côtière en Europe pendant le Paléolithique supérieur. Considérations à partir d'une base de données archéologiques. In : H. Richard et A. Vignot (Ed.), Équilibres et ruptures dans les écosystèmes depuis 20000 ans en Europe de l'Ouest, Actes du colloque international (Besançon, septembre 2000). Besançon: Presses universitaires franc-comtoises, p. 165-174.

SERANGELI J. 2003 - La zone côtière et son rôle dans les comportements alimentaires des chasseurs-cueilleurs du Paléolithique supérieur. In : M. Patou-Mathis et $\mathrm{H}$. Bocherens (Ed.), Le Rôle de l'environnement dans les comportements des chasseurs-cueilleurs préhistoriques. Oxford: Archaeopress (BAR International Series 1105), p. 67-82.

SITZIA L. 2014 - Chronostratigraphie et distribution spatiale des dépôts éoliens quaternaires du Bassin Aquitain. Bordeaux, université de Bordeaux, thèse de doctorat, 341 p.

SITZIA L., BERTRAN P., BAHAIN J.-J., BATEMAN M.D., HERNANDEZ M., GARON H., DE LAFONTAINE G., MERCIER N., LEROYER C., QUEFFELEC A., VOINCHET P. 2015 - The quaternary coversands of southwest France. Quaternary Science Reviews, 124, p. 84-105.

SONNEVILLE-BORDES D. de, LAURENT P. 1983 - Le phoque à la fin des temps glaciaires. In : F. Poplin (Ed.), La Faune et l'homme préhistoriques. Paris: Société préhistorique française, p. 69-80.

STRAUS L.G., CLARK G.A. (Ed.) 1986 - La Riera Cave: Stone Age Hunter-Gatherer Adaptations in Northern Spain. Tempe : Arizona State University (Anthropological research papers 36), $499 \mathrm{p}$.

STROHALM M., HASSMAN M., KOSATA B., KODICEL M. 2008 mMass data miner: an open source alternative for mass spectrometric data analysis, Rapid Communications in Mass Spectrometry, 22, 6, p. 905-908.

SYNAL H.-A. 2013 - Developments in accelerator mass spectrometry. International Journal of Mass Spectrometry, 349350, p. $192-202$.
SWARTZ S. 2014 - Family Eschrichtiidae (Gray Whale). In : D.E. Wilson et R.A. Mittermeier, (Eds.), Handbook of the Mammals of the World: Volume 4, Sea Mammals. Barcelone : Lynx Edicions, p. 222-241.

SYNAL H.-A., STOCKER M., SUTER M. 2007 - MICADAS: A new compact radiocarbon AMS system. Nuclear Instruments and Methods in Physics Research Section B: Beam Interactions with Materials and Atoms, 259(1), p. 7-13.

TABORIN Y. 1993 - La Parure en coquillage au Paléolithique. Paris : CNRS (suppléments à Gallia Préhistoire, 29), 538 p.

TAYLOR M.A. 2000 - Functional significance of bone ballast in the evolution of buoyancy control strategies by aquatic tetrapods. Historical Biology, 14, p. 15-31.

VANHAEREN M., D'ERRICO F. 2001 - La parure de l'enfant de la Madeleine (fouilles Peyrony). Un nouveau regard sur l'enfance au Paléolithique supérieur. Paleo, 13, p. 201-240.

VAN DOORN N.L., HOLLUND H., COLLINS, M.J. 2011 - A novel and non-destructive approach for ZooMS analysis: ammonium bicarbonate buffer extraction. Archaeological and Anthropological Sciences, 3(3), p. 281-289.

VON HOLSTEIN I.C.C., ASHBY S.P., VAN DOORN N.L., SACHS S.M., BUCKLEY M., MEIRI M., BARNES I., BRUNDLE A., COLLINS M.J. 2014 - Searching for Scandinavians in preViking Scotland: molecular fingerprinting of Early Medieval combs. Journal of Archaeological Science, 41, p. 1-6.

WELKER F., COLLINS M.J., THOMAS J.A., WADSLEY M., BRACE S., CAPPELLINI E., TURVEY S.T., REGUERO M., GELFO J.N., KRAMARZ A., BURGER J., THOMAS-OATES J., ASHFORD D.A., ASHTON P.D., ROWSELL K., PORTER D.M., KESSLER B., FISCHER R., BAESSMANN C., KASPAR S., OLSEN J.V., KILEY P., ELLIOTT J.A., KELSTRUP C.D., MULLIN V., HOFREITER M., WILLERSLEV E., HUBLIN J.-J., ORLANDO L., BARNES I.. MACPHEE R.D.E. 2015 - Ancient proteins resolve the evolutionary history of Darwin's South American ungulates. Nature, 522(7554), p. 81-84.

ZICKEL M., BECKER D., VERHEUL J., YENER Y., WILLMES C. 2016 - Paleocoastlines GIS dataset. CRC806-Database, doi: $10.5880 /$ SFB806.20 